\title{
Indigenous People's Environmental Concerns: The Missing Piece in Ongoing Administrative and Political Decentralization in Africa
}

\author{
George Atisa ${ }^{1}$, Aziza Zemrani ${ }^{1} \&$ Matthew Weiss ${ }^{1}$ \\ ${ }^{1}$ University of Texas Rio Grande Valley, Edinburg. Texas, USA \\ Correspondence: George Atisa, University of Texas Rio Grande Valley, ELABN 229A, 1201 W. University \\ Drive., Edinburg, Texas, 78539. USA. Tel: 1-786-253-8837; 1-956-665-2545. E-mail: george.atisa@utrgv.edu
}

Received: May 20, 2018

doi:10.5539/jsd.v11n5p288
Accepted: August 2, $2018 \quad$ Online Published: September 29, 2018

URL: https://doi.org/10.5539/jsd.v11n5p288

\begin{abstract}
Decentralization is assumed to make national governments more accountable and enables local people to get involved in governance decisions. This study examines the relationships and whether decentralization activities, policies and regulations support indigenous concerns for the environment. Much of the pristine and local lands globally have already been degraded through overexploitation of natural resources leading to significant loss of environmental benefits to people, especially the marginalized and indigenous communities. Using citizen-over-state and state-over-citizen theory, the influence of national level policies on local policies and vice versa is examined. Two sets of data are analyzed: reports from conservation organizations and peer reviewed publications. The other data is obtained from the World Bank and the Food and Agricultural Organization data base. All African countries are analyzed. The findings show that many national policies and regulations do not support and have no relationship with indigenous peoples' environmental values, thus undermining local sustainable lifestyles. The more focus on economic development as an outcome is turning out to be a dominant force in driving exploitation of resources and eroding indigenous peoples' cultural and environment values. While a few policies and regulations have some correlation with indigenous values, they have no significant influence in terms of producing sustainable local level environmental outcomes.
\end{abstract}

Keywords: decentralization, indigenous, environmental values, sustainable, policies and regulations, poverty

\section{Introduction}

Governments that have been organizing under the framework of decentralization to create more economic opportunities and make public institutions more accountable to citizens have continued to face implementation challenges and mixed outcomes. Decentralization, which is focused mainly on expanding economic opportunities, is opening the most pristine, intact and biologically rich landscapes to uses that may not be compatible with the cultural and environmental values of many indigenous communities. While decentralization does not follow the original framework of either dispossession or displacement of communities normally used to create protected areas (Stevens, 2014), it is designed to give responsibility to indigenous communities to exploit natural resources for their perceived economic benefits while meeting national economic objectives.

The social framework of managing local resources to meet local needs is being transformed and expanded to include national needs through decentralization reforms. Many of the services such as delivery of water, electricity, healthcare, education, town planning and land use (Vollan, 2012) that were formally the responsibility of central governments now rest on the shoulders of local governments. Virtually all local governments in Africa continue to rely on central governments for funding, thus making them more accountable to national governments and not local citizens. In addition, these countries depend on natural resources and external aid from donors and international lenders for government revenue (Assan \& Hunt, 2018; Qayyum et al., 2014) that is often too meagre to sustain government programs. Therefore, most developing countries are in a constant search for opportunities and sources of additional revenue. When these opportunities are limited to dependence on natural resources, this leads to accelerated degradation of the same, resulting in reduced environmental benefits to people, especially the marginalized and indigenous communities (Reij et al., 2016; FAO, 2015; Assan \& Beyene, 2013).

Policies and governance initiatives that do not strengthen indigenous environmental values may drive indigenous and local communities towards overexploitation of natural resources, leading to increased vulnerability to 
climate change impacts and other natural shocks. This raises two important questions: to what extent do decentralization objectives promote the environmental concerns of indigenous communities and at the same time serve the economic development objectives of central governments? What type of relationship exists between various policies and economic initiatives with indigenous environmental values? The study analyzes the impact of various policy tools that are designed to guide the implementation of local and national economic development objectives to determine their relationship with the environmental concerns of indigenous communities.

Decentralization is the transfer of responsibility, planning, decision-making and authority to local governments (Kadirbeyoglu, 2017; Crawford \& Hartmann, 2008). It is argued that decentralization is making bureaucracies more efficient and accountable to citizens as well as strengthening local communities in the management of their resources (Smoke, 2015; Wever et al., 2012). Accountability is attained through the transfer of administrative, political and social responsibilities to local governments where it is possible to make use of local knowledge and information in decision-making (Kadirbeyoglu, 2017; Yussof et al., 2016). Almost all countries in Africa have already implemented many of the decentralization reforms (Crawford \& Hartmann, 2008). International donors such as the World Bank have lauded decentralization as a cure-all for budgetary deficits, accountability and efficient service delivery by governments of developing countries (Dickovick, 2014). Developing countries seem to have seized the opportunities expected from decentralization without examining all the consequences of this well-intentioned policy.

From the perspective of local cultural and indigenous values, this study argues that decentralization is changing local people's priorities, their attitudes and the manner in which resources are used. It is creating local collective action that is profit motivated and thus supports economic forces that are intended to fulfill the economic aspirations of the central government (Crawford \& Hartmann, 2008).

This study is important because understanding and fostering the indigenous concerns for the environment is also about protecting global species whose value to mankind is incomparable from the standpoint of ecological and human health. Local and indigenous communities live on lands that house biologically outstanding global resources covering approximately $24 \%$ of the world's land with $80 \%$ of the world's healthy ecosystems (IUCN, 2015; Global Environmental Facility, 2007). The challenges associated with decentralization and how emerging policies are disrupting support for the environment at local levels and the lives of indigenous communities has received little scholarly attention.

This study contributes to the literature because it examines the extent to which environmental and cultural values in general are being influenced and altered by modern governance policies across the African continent. Africa constitutes an ideal case study for the pitfalls of decentralization. Not only do indigenous communities across the continent live in the most biologically rich and diverse places; they have also been marginalized economically through civil wars and non-recognition of land rights (United Nations 2009) and stand to lose the most when natural resources are degraded. In addition, almost all countries on the continent are heavily dependent on natural resources for economic development, all but locking them into a "business-as-usual" trajectory of environmental degradation. This poses a formidable set of obstacles for even the best conceived innovations in governance.

One example of a policy innovation that has been widely implemented in Africa with decidedly mixed outcomes is the removal of indigenous communities from their lands to create protected areas under the management of state administrations (Stevens, 2014). Whatever environmental benefits such protected areas may further, they are broadly perceived as having deprived local communities of the use of and access to their ancestral lands (Stevens, 2014). In addition, many of the protected areas in Africa are funded by donors from outside the continent. This example illustrates how ostensibly sound and environmentally-friendly policies favored by international donors often produce negative unintended consequences that prove detrimental to both indigenous communities and the environment alike. Against this backdrop, we observe a disturbingly familiar pattern playing out in Africa in the implementation of decentralization initiatives, owing to the same systematic neglect of the needs and concerns of the very communities who stand to be the most directly impacted (United Nations, 2009).

Decentralization could unleash another wave of dispossession where indigenous communities might relinquish their guardianship and defense of natural resources to the state for short-term economic benefits, if not implemented correctly. In resource dependent economies with limited revenue sources, as is prevalent in Africa, it is difficult to visualize an outcome where economic development and poverty reduction can be attained without the intensive use of natural resources to finance community programs. However, while 
resource-intensive development can meet economic objectives, it will most likely undermine the ability of local and indigenous communities to protect the environment. This is a conundrum that merits further investigation and therefore the following two hypotheses are tested:

Hypothesis 1. Decentralization is not making national and local governments more accountable to citizens as national governments continue to dominate the policy environment with a focus on economic development and no support for indigenous concerns for environmental values.

Hypothesis 2. Management initiatives being developed at both local and national levels have no direct relationship with indigenous values and thus are eroding indigenous efforts to protect the environment.

\section{Literature and Theoretical Review}

Administrative and political decentralization should consist of much more than just delegation of responsibility and devolution of power to local institutions. It should also involve the empowerment of communities so that they can move away from negative tendencies that come with social and economic development activities (Kumar et al., 2015; Stevens, 2014) towards sustainable use and protection of natural resources. In almost all countries, the demand for resources to meet development goals often exceeds the supply. This leads to overexploitation and damage to the environment. The costs arising from damage to the environment are not easy to quantify and even if it was, since no one individual is asked to meet those costs, they can easily be ignored and can easily produce what Garrett Hardin called, "the tragedy of the commons."

The motivations highlighted as drivers for decentralization include the promotion of economic opportunities, empowerment of local governments and efficient delivery of public services (Crawford \& Hartmann, 2008). These opportunities have brought about life-changing choices that include extractive developmental tendencies. Transfer of responsibility to local governments and community empowerment has created incentives to exploit local resources to meet the shortfall of funding from the national governments. Local governments are expected to balance the preferences of local communities with national goals and also provide those communities with greater influence in decision-making.

Indigenous peoples' concern for environmental quality is based on an accumulated vast amount of ecological knowledge and cultural values that span hundreds of years (WWF, 2000). For many years, conservation decisions have remained local and culturally driven (Smoke, 2015). With decentralization, local decision-making regarding the use of natural resources is being greatly influenced by the changing economic priorities of the national governments (Turner, 2009). At the same time, in countries that have implemented decentralized governance, the realities on the ground are that national governments continue to steer decision-making through the power of the purse (Turner et al., 2011). In many other aspects of social and economic development, local governments continue to be bound to the interests and priorities of national authorities. Local governments do not have adequate capacity to moderate this top-down influence, especially when presented as the most viable model for local development.

Transfer of governance powers to the lowest level of government enables entrenchment and consolidation of democratic values, as well as subsidiarity principles and practices (Crawford \& Hartmann, 2008). Subsidiarity principles exist when decision-making is exercised at the lowest levels of government. The greatest challenge is that environmental issues are not high on the priority list for decentralized governments. As currently structured, the decentralization framework lends the impression that there is support for indigenous values that include the ability to choose development options that are locally determined and that tend to improve the entire community (WWF, 2000). However, research has begun to demonstrate that decentralization as well as globalization are skewing local priorities towards resource-intensive, unsustainable economic development, and eroding cultural and environmental values (United Nations, 2009). At the same time, a dilemma is created, as the imperative of accountability to citizens pushes local leaders to adopt policies that undermine environmental and indigenous values as they are confronted with services delivery responsibilities in the face of insufficient funding from national governments.

\subsection{Intergovernmental and Community Relationships}

In 1997, the then Director General of the World Wildlife Fund International (WWF-International) Dr. Claude Martin said, "The power to act has moved away from governments and the real force for environmental improvement lies with the people. Individual and community actions are crucial to affecting change" (WWF, 2000). Without constitutional and legislative mandates specifically designed to shape the lifestyles of indigenous and local communities as they adapt to change coming from both within and outside, their power to act locally and continue to generate positive change is in limbo (IUCN, 2015). The statement by WWF Director General is a 
double-edged sword, meaning that relationships between national governments and local communities may either bring about positive or negative changes. The tools, education and nature of support given to indigenous communities as they fit themselves into a global environment is determined by how much they can influence their governments as opposed to being influenced by them.

Garret \& Rhine (2006) explain two theories concerning relationships between government and the society. The relationships originate from the citizen-over-state and state-over-citizen theories. The citizen-over-state theory is concerned with the government response to citizen demands. The demand for government services comes from either individuals or organized interest groups. Indigenous peoples are an example of an interest group that is able to effectively apply political pressure on governments to influence policy towards the group's desired benefits. Local groups have greater respect for local rules regarding the use of resources and have more knowledge to identify and prioritize their environmental concerns more accurately (Ran, 2017; Tacconi, 2007).

The second category is state-over-citizen theory which looks at expanded government from the perspectives of incentives facing government bureaucrats. Examining decentralization from the state-over-citizen perspective, there are two ways the government can influence the citizens: expanded bureaucracy through more public institutions and the "fly-paper effect" hypothesis (Garret \& Rhine, 2006), which refers to increased grants from central to local governments designed to give more fiscal responsibility to local governments. Both the bureaucratic and fly-paper effect may not deliver on decentralization objectives because it is argued that sufficient power is not transferred to local institutions and government accountability towards local communities is inadequate (Tacconi, 2007).

The national and local governments are often on the opposing extreme ends of the power spectrum as each level has own interests to pursue and in so doing, end up contradicting, compromising or at times defeating interests of the other (Castro \& Nielsen, 2001). Transfer of power to local institutions provides opportunities for local officials to be accountable to the central government as well as to local communities. The side that wields more power tends to determine priorities, objectives and sometimes outcomes. The factors that determine environmental outcomes according to Tacconi (2007) fall into three categories: first, the legal structure; second, the mediating factors; and finally, the local government decision-making sphere.

A study by Duncan (2007) on the impacts of decentralization on indigenous communities in Indonesia found that decentralization was viewed as one way to gain control of the management of natural resources by indigenous communities. These findings on benefits to indigenous communities from decentralization are mixed. On one hand, decentralization is supposed to enhance accountability, bring about better policy outcomes and reduce corruption. On the other hand, decentralization presents local governments with opportunities to try and generate local income by exploiting natural resources more as some percentage of locally generated incomes is left with local governments. This goes against the conventional wisdom that communities that live in close proximity to resources will more likely adopt sustainable resource use practices than outsiders (Duncan, 2007).

\section{Methodology}

Both qualitative and quantitative analytical techniques are used. Qualitative analysis provides insights into the various current research findings and the status of activities by organizations working with indigenous communities. A quantitative approach is used to determine the nature and significance of relationships between various policies and decentralization initiatives with indigenous values.

\subsection{Data sources}

Data from peer reviewed literature and reports of conservation organizations covering all countries in Africa between the year 2000 and 2015 are analyzed. Organizational reports from international conservation organizations: the International Union for Conservation of Nature (IUCN), World Wildlife Fund (WWF), Global Environmental Facility (GEF), The Convention on Biodiversity, the World Bank and the UN Food and Agricultural Organization (FAO) are analyzed. A total of 13 peer reviewed articles and nine reports of conservation organizations are analyzed. These articles were selected based on four criteria:

i. Were published between 2000 and 2015

ii. Discuss public-sector reforms in relation to decentralization covering the entire continent in general.

iii. Touch on some aspects of land use or natural resources in relation to decentralization

iv. Examine indigenous communities in relation to public sector reforms.

\subsection{Qualitative Analysis}

Qualitative analysis using NVivo10 is conducted on the literature and organizational reports to determine the 
emerging relationships, how decisions are made, and how changes are manifesting themselves (Saldana, 2013; Thomas, 2006). Nvivo is among the most robust software used to conduct qualitative data analysis. Its strengths include the way information can be organized, managed and analyzed. It provides techniques to code and classify information, thus enabling relationships to emerge between topics, goals and outcomes in sample documents. Words with similar meaning and following a pattern are placed into a code. Codes form a structure known as a theme that helps to make sense of the direction and type of changes taking place.

This is followed by a thematic analysis using inductive and deductive analytical techniques. A general inductive analysis is conducted to summarize the literature and to identify the objectives and specific initiatives that support the implementation of decentralization in greater detail (Fereday \& Muir-Cochrane, 2006).

Deductive analysis involves putting together the specific decisions and social and economic developments to be able to see the dominant and more frequent concepts that start to emerge from the literature. This makes it easy to visualize the impacts of actual policy on the local jurisdictions.

\subsection{Quantitative Analysis}

A quantitative analysis is conducted based on four questions obtained from a 2015 FAO survey. The questions in the survey are used as proxies for measuring how policies as defined within these questions could be affecting and changing indigenous values: (i) How much forest area is managed for the production of soil, water, ecosystem services, cultural and spiritual values? (ii) What forest policy and regulatory frameworks exist to support the implementation of sustainable forest management? (iii) What percentage of forest area is under a management plan? (iv) How are stakeholders involved in the decision making for publicly held forest lands? The data related to these four questions are correlated with indigenous values, the Ecosystems Services, Ecological, Cultural and Social Values to measure the strength of the relationship.

The model also controls for foreign direct investments (FDIs) as these are deemed to be geared towards exploitation of natural resources as most locally generated revenues go towards supporting national and local programs, not investments. The FDIs are therefore used as proxies for measuring national investments. The presence of policies and regulations are either a 'yes' or 'no' answer. The 'yes' answer is represented by one (1) and 'no' is represented by zero (0) dummy variables. Other independent variables include local/indigenous peoples' participation in both planning and decision making, forest areas under some form of sustainable management plans, the existence of national and local policies, as well as national and local regulations.

Indigenous values (IV) are dependent upon the percentage of forests under management plans (FMP), percentage of rural poverty of GDP, National Investments (FDI) and national and local policies and regulations. Policies and regulations are dummy variables.

$$
\begin{gathered}
I V=\beta_{0}+\beta_{1} F_{m p}+\beta_{2} R P_{g d p}+\beta_{3} N I_{f d i}+\beta_{4} \sum_{0}^{n} N P_{p u}+\beta_{5} \sum_{0}^{n} N P_{p r}+\beta_{6} \sum_{0}^{n} N R_{p u}+\beta_{7} \sum_{0}^{n} N R_{p r}+ \\
\beta_{8} \sum_{0}^{n} L P_{p u}+\beta_{9} \sum_{0}^{n} L P_{p r}+\beta_{10} \sum_{0}^{n} L R_{p u}+\beta_{11} \sum_{0}^{n} L R_{p r}+P_{p o r}+\varepsilon
\end{gathered}
$$

Where:

$I V=$ Indigenous values (soil, clean water, ecosystems services, spiritual and cultural values)

$\beta_{0}=$ Constant

$F_{m p}=$ Percentage of forests under management plans

$R P_{g d p}=$ Rural poverty percentage of GDP

$N I_{f d i}=$ National investments represented by Net Foreign Direct Investments

$\sum_{0}^{n} N P=$ National public policies where $p u$ refers to public and $p r$ to private policies

$\sum_{0}^{n} N R=$ National regulations where $p u$ refers to public and $p r$ private regulations

$\sum_{0}^{n} L P=$ Local policies, $p u$ and $p r$ are as explained above

$\sum_{0}^{n} L R=$ Local regulations

$P_{\text {por }}=$ Participation in planning phases - planning phase, operation and review phase

\section{Findings}

The findings are presented in two parts, first, the findings from the qualitative analysis of the literature and reports of conservation organizations. The second part of the findings presents the quantitative analysis of the significance and relationships between various government initiatives and indigenous values.

The "citizen-over state" and "state-over citizen" theory (Garret \& Rhine, 2006) qualitative analysis of the 
literature and program reports of conservation organizations shows negative emerging relationships between decentralization activities and indigenous environmental values. Decentralization has created a strong and structured relationship between national and local governments and by extension with the livelihoods and activities of local communities, but does not contribute positively towards environmental protection. This summary statement from the analyzed literature shows how local and national governments desire to create economic wealth as the primary goal, yet with little regard to environmental impacts.

"Central government priorities in planning and implementing developmental activities is often motivated by a variety of factors including regional, political \& ethnic concerns; the immediate needs of local communities are either not assessed or left on the wayside."

Indigenous cultural values and concerns for the environment are becoming eroded by many of the policies examined in this study. National objectives are slowly changing local values and priorities, leading to increased intensity in the use of local resources.

Local political and administrative problems are compounded by the adoption of the national development framework in regions that have limited capacity to deal with and meet all of the local development needs. Existing literature and organizational reports demonstrate that local needs are not being adequately met to the satisfaction of local citizens. As reflected in the following summary from the literature, decentralization is founded on the transfer of responsibility and services to local governments but does not transfer all the powers to local leaders as well as the much-needed resources.

"In some cases, decentralization may not be a real transfer of power but rather an opportunity for politicians and power groups to capture power, and in extracting rent, at the sub-national level. The main concern is the lack of understanding precisely what is meant by decentralization and its core attributes."

Unless complemented by clear conservation and sustainable use goals, these developments will do irreparable damage to cultural and indigenous values.

The study finds evidence that local economies are being transformed in ways that are harmful to natural resources and the traditions of local communities. Decentralization reforms are often presented as locally focused, but these mask the ongoing dominance of strong national economic development objectives that are in many respects out-of-step with fundamental indigenous values. As currently conceptualized, decentralization tends to place greater emphasis on economic outcomes as opposed to basic human factors such as empowerment and concerns for the environment. In a workshop on decentralization in 2005 in Senegal, West Africa, conducted by conservation organizations, participants expressed three short-falls:

"The civil society's participation, and empowerment, in decentralized processes are not adequate and by and large are poor. Secondly, there are significant capacity deficits both in the institutional structures and professional personnel chosen to man decentralized processes. Thirdly, decentralization, as designed, is not empowering the poor."

\subsection{Qualitative Findings}

A summary of the findings from both the literature and organizational reports is presented, followed by the emerging themes and finally the relationships to indigenous values. It is apparent that the primary focus of decentralization initiatives is not on indigenous values and sustainable lifestyles. The analyzed reports of conservation organizations generally agree that:

"the prerequisites for effective decentralization are still emerging and are not altogether clear in their focus. Effective decentralization invariably means that there is devolution of power and that participation, empowerment and accountability of communities is attained."

Existing measures of the success of decentralization outcomes falls short of the actual devolution of power, participation, empowerment and accountability. Much of the problem can be attributed to an inordinate focus on measuring effective decentralization in terms of outputs such as the number of institutions created, or the amount of money spent rather than on outcomes in terms of real impacts. Outcomes show the real impact on specific sectors. Although most of the literature analyzed argues that decentralization leads to better public policy implementation outcomes, this is not the case when indigenous environmental values are considered.

There are also major gaps from the perspective of accountability roles between local and national governments. These gaps have also been identified between institutions, both public and private, and individual communities. Rather than community-government relations, patronage due to weaknesses in state structures is enabling elites 
to control the entire process from national to local politics. Added to this complexity, according to FAO is the low capacity of existing and new institutions to address specific environmental problems as local regions start to significantly participate in the economic development of an entire country.

There is a skewed focus toward more development and less enthusiasm for sustainable use of resources by many local governments. This is because "many countries do not legally recognize indigenous people's customary laws on collectively owned lands, land-use rights and management practices" (Stevens, 2014). All forms of decentralization, political, administrative and fiscal, do not have a built-in mechanism to facilitate respect for and recognition of indigenous peoples' values, especially when they conflict with economic development goals. One good example found in the reports of conservation organizations is that there is no "legal right to land ownership by indigenous communities (IUCN, 2015)", thus making these groups stakeholders of limited value.

Findings from ongoing research point towards development practices that are building economic platforms favoring "local extraction of resources to finance both local and national development" (peer reviewed literature) There is a greater desire to increase production of local resources to increase revenue that is shared between local and national government. Promotion of economic development has the potential to negatively impact natural habitats, especially when economic development practices are not grounded in indigenous values and respect for the environment. The lack of deference to indigenous concerns for the environment is also demonstrated by how key local programs and policies are funded.

\subsection{Emerging Themes from Literature and Organizational Reports}

The emerging themes are developed from the meaning and relationships between the most frequently used words. These themes are developed to make it easy to understand the state of resources, relationships and evidence of the impact of policy or the effectiveness of conservation programs. From a broad perspective, these themes fall into two policy approaches: technical policy driven themes and the democratic or politics driven themes. Making this distinction helps to show how decentralization and environmental narratives potentially go towards supporting or undermining sustainable use of resources.

Technical or policy-driven themes refer to the governing frameworks, rules and institutions. "There are strong legal frameworks within national constitutions and local government that support transfer of power to local governments so that local people can have greater influence over government" (Crawford \& Hartmann, 2008). On the other hand, "conservation policies in Africa are largely defined by international conventions, for example, the Convention on Biological Diversity, to which individual national governments are signatories" (Homewood, 2008) often with little-to-no input from local communities. The lack of involvement of local communities at the initial policy formulation stages make it difficult for such policies to be adopted. Conservation organizations see emerging challenges as originating from national government agendas that are driven by international policies not often aligned with local environmental believes. There also exists a strong presence of powerful elites at both the local and national government levels, weak local governance structures and inadequate resources to meet both economic and environmental needs nationally.

As demonstrated in table 1, development goals that serve and address environmental concerns for local and indigenous peoples are placed on a back seat relative to national development priorities. 
Table 1. Policy driven themes

\begin{tabular}{|c|c|c|}
\hline Key Word & Policy Driven Categories & Emerging Themes - Policy Related \\
\hline Community & $\begin{array}{l}\text { Peoples, indigenous, members, gatherers, } \\
\text { Native, Dwellers, Participation, Village, } \\
\text { Settled, Commons, Needs }\end{array}$ & $\begin{array}{l}\text { No recognition of values, culture and respect } \\
\text { for indigenous communities. Policies that } \\
\text { support collective management and use of } \\
\text { common resources (forests, water, soil..) with } \\
\text { practices } \\
\text { that adhere to sustainable use }\end{array}$ \\
\hline Programs & $\begin{array}{l}\text { Programs, Projects, Results, Performance, } \\
\text { Decision, relations, expansion, situation, } \\
\text { Assessment, implementation, social, } \\
\text { Institutions, Practices, Work }\end{array}$ & $\begin{array}{l}\text { More about expanded economic development } \\
\text { and extractive use of resources for more } \\
\text { revenue to be shared between local and } \\
\text { national government. } \\
\text { There is also a greater focus on poverty } \\
\text { alleviation. }\end{array}$ \\
\hline Quality & Situation, Limited, Successful & $\begin{array}{l}\text { No criteria for measuring impact and outcomes } \\
\text { of decentralization to determine type of } \\
\text { changes. Greater focus on poverty alleviation } \\
\text { continues to negatively impact the quality of } \\
\text { the environment. }\end{array}$ \\
\hline Resources & $\begin{array}{l}\text { Land, Property, Areas, Place, Rural, } \\
\text { Traditional, Environment, Forests, } \\
\text { State, Vegetated, Resources, Conflicts, } \\
\text { Biological, Situation, Assessment, } \\
\text { Information, Conditions. }\end{array}$ & $\begin{array}{l}\text { Restoration of ownership and respect of } \\
\text { ownership rights of indigenous communities is } \\
\text { not a priority. Although decentralization has } \\
\text { been ongoing for almost two decades, major } \\
\text { initiatives that support environmental issues } \\
\text { seem to be stuck at infancy stages. }\end{array}$ \\
\hline
\end{tabular}

Findings from the analysis of conservation organizations reports show that "there is discontent around a perceived lack of respect by government and others for cultural identity and heritage, leading to increased competition for resources such as land and forests for which the local community feels ownership." Recognition of indigenous values and the desire to incorporate them in the decision-making process is not well developed. Policy driven themes show a state-over-citizen approach to decentralization where program objectives in most decentralized systems do not draw from the communities that they are serving.

Emerging themes in table 1 show the challenges that environmental concerns continue to face as decentralization initiatives across Africa take root. Communities describe themselves as indigenous, gatherers, and dwellers with common needs. Programs are described as projects geared towards specific results, performance and relationships. As seen from the table, these results and performance have more to do with poverty alleviation than environmental concerns. The measure of success is based on the level of sub-national expenditures on service delivery, an indicator that is fundamentally flawed as it does not track where the money goes and expected outcomes from such expenditures.

Themes related to politics show a divergence of interests between all stakeholders: communities, local leaders, and local and national institutions. Stakeholders do not have a unified position on accountability, priorities and management of natural resources. Research, data and expertise on scientific ideas is inadequate; hence, there is greater reliance on political decisions from appointed leaders who may not have the right expertise and knowledge of environmental conservation.

Politics-driven themes shown in table 2 show how decisions that drive policy are made. The process of decision-making looks very good on the surface. Decision-making is based on well-founded ideas, interest groups and consensus. However, imbalanced relations between the national government and local stakeholders who lack comparable access to the corridors of power often mean that the fundamental rights and priorities of the latter are disregarded. 
Table 2. Politics driven themes

\begin{tabular}{|c|c|c|}
\hline Key Word & Politics Driven Categories & Emerging Themes - Politics Related \\
\hline Interests & $\begin{array}{l}\text { Studies, Idea, notes, Science, } \\
\text { Interests, Collections }\end{array}$ & $\begin{array}{l}\text { Current studies fall short in connecting } \\
\text { indigenous issues broadly to ongoing } \\
\text { policy, political, administrative, economic } \\
\text { and environmental changes }\end{array}$ \\
\hline Support & $\begin{array}{l}\text { Settings, Positions, Public, Collection, } \\
\text { Means, Council, Political, Systems, } \\
\text { Control, Improve, Appointed, Level, } \\
\text { Assemblies }\end{array}$ & $\begin{array}{l}\text { No clear support toward indigenous } \\
\text { concerns for the environment, values, and } \\
\text { culture from the national government. } \\
\text { This gap is filled by international donors } \\
\text { and conservation organizations. }\end{array}$ \\
\hline Representatives & $\begin{array}{l}\text { Representatives, Accountability, } \\
\text { Legislation, Power, Ruling, Politics, } \\
\text { Councilors, Politicians, Common, } \\
\text { Conflict }\end{array}$ & $\begin{array}{l}\text { Local and indigenous peoples do not have } \\
\text { sufficient influence over their } \\
\text { representatives. Indigenous people value } \\
\text { and protect common resources but conflicts } \\
\text { emerge because authorities at different } \\
\text { levels in government have different } \\
\text { priorities. }\end{array}$ \\
\hline
\end{tabular}

The political will of elites at both national and local levels have been found to skew resources to the benefit of a few. The statement below is extracted from conservation organizations and peer reviewed documents, and reveals that elites can prevent effective implementation of decentralization polices that benefit local communities through national funding. This is because those at the local government level lack sufficient democratic capacity to create accountable structures between communities and national governments directly.

"While the rationale for decentralization is undoubtedly sound, the practice has been aiding the threats posed by webs of vested interests, corruption, and dominant political groups. Larson in her study on democratic decentralization in the forestry sector observes that democratic decentralization is rarely implemented and that a large share of decision-making powers, resources and benefits from forests remain centralized."

There are still conflicts ranging from local versus national interests to the control of resources, representation at the decision-making table, and defining who is accountable to whom. Citizens continue to play a lesser role in both national and local politics despite expanded local representation. This confirms our first hypothesis that communities are bound to the preferences and interests of national governments rather than vice versa. This is undermining environmental values engrained in indigenous communities' lifestyles.

\subsection{Quantitative Findings}

Decentralization is being implemented alongside other policies designed to ensure the success of entire communities. Correlations between various policies, agreements and regulations, on one hand, and indigenous cultural and spiritual values, on the other, show a very weak relationship. In addition, many of these variables have no significant impact on indigenous communities' lifestyles and cultural values, as well as their capacity to moderate and influence national government policies that get passed down to local levels.

The primary concern for indigenous peoples is the soil, clean water and other ecosystem services that support their social, economic, cultural and spiritual values. The quality as well as the setting aside of forest resources specifically to address these concerns does demonstrate the extent to which support is provided by ongoing policies and administrative developments. Indigenous concerns for the environment are therefore measured by the presence of forests designated for cultural, spiritual, social and ecosystem values.

Table 3 shows the correlation between indigenous values, various policies, and management and conservation initiatives. The policies, regulations and participation in planning as well as the impact of Foreign Direct Investments (FDIs) and Poverty are correlated with indigenous values using Spearman's rank correlation. 
Table 3. Correlations of various initiatives with indigenous values

\begin{tabular}{|c|c|c|}
\hline $\begin{array}{c}\text { Country initiatives in the era of } \\
\text { decentralization }\end{array}$ & $\begin{array}{l}\text { All Countries; those reporting } \\
\text { and those not reporting Changes } \\
\text { in Ecosystem Services, Cultural, } \\
\text { Ecological and Social Values } \\
\text { (Indigenous Values) }\end{array}$ & $\begin{array}{l}\text { Only countries reporting } \\
\text { Changes in Ecosystem } \\
\text { Services, Cultural, Ecological } \\
\text { and Social Values (Indigenous } \\
\text { Values) }\end{array}$ \\
\hline National Public Policies & -0.040 & -0.034 \\
\hline National Private Policies & -0.043 & -0.034 \\
\hline National Public Regulations & $-0.321 *$ & $-0.466^{*}$ \\
\hline National Private Regulations & -0.187 & -0.263 \\
\hline Regional Public Policies & -0.213 & -0.314 \\
\hline Regional Private Policies & -0.223 & -0.327 \\
\hline Regional Public Regulations & -0.242 & -0.367 \\
\hline Regional Private Regulations & -0.218 & -0.327 \\
\hline Provincial Public Policies & -0.206 & -0.294 \\
\hline Provincial Private Policies & -0.206 & -0.302 \\
\hline Provincial Public Regulations & -0.235 & -0.327 \\
\hline Provincial Private Regulations & -0.213 & -0.302 \\
\hline Local Public Policies & -0.209 & -0.302 \\
\hline Local Private Policies & -0.213 & -0.302 \\
\hline Local Public Regulations & -0.045 & -0.073 \\
\hline Local Private Regulations & -0.096 & -0.129 \\
\hline Participation at Planning Phase & -0.035 & -0.051 \\
\hline Participation at Operation Phase & -0.043 & -0.066 \\
\hline Participation at Review Phase & -0.188 & -0.268 \\
\hline Foreign Direct Investments & -0.130 & -0.180 \\
\hline Poverty as $\%$ of GDP & -0.021 & -0.078 \\
\hline Forests under plan management & 0.128 & -0.192 \\
\hline
\end{tabular}

*. Significant at $95 \%$ level.

**. Significant at $99 \%$ level.

There are 47 countries that reported their data but only 22 reported on the indigenous values variable. First, all countries, including those that did not report on the changes in indigenous values, are correlated. Those that did not report on indigenous values were assigned the value zero. Then, only countries reporting the changes in indigenous values are correlated. The outcomes are shown in columns two and three of Table 3 respectively. The correlation outcomes with absolute values of less than 0.25 mean that there is no relationship between the variable and indigenous values. Values between 0.25 and 0.50 can be classified as showing a weak relationship and those above 0.50 only a strong relationship. Apart from national policies that show a weak relationship, all other policies, regulations, participation in planning, investments and poverty programs have no relationship with indigenous values.

Only for one variable, 'National Public Regulations', is there a discernible relationship with indigenous values. The value of this relationship is -0.321 when all countries are considered and 0.466 , if only those countries reporting changes in indigenous values are considered. Both these values are significant at the $95 \%$ level. The negative relationship means that regulations do not support indigenous values. Said differently, public regulations have very little to do with protecting or working to improve indigenous values. Although they do not have a direct relationship with indigenous values, the negative sign indicates one characteristic all of these 
management and administrative initiatives share: their tendency to erode indigenous values. One other noticeable outcome is the lack of a relationship between forests under management plans with indigenous values. This counterintuitive result may be attributed to a tendency to plant forests for commercial purposes rather than with an eye towards contributing to the preservation of indigenous peoples' environmental concerns.

Although only one variable has a relationship with indigenous values, a regression is conducted to determine the significance and magnitude of these variables.

Table 4 shows the ' $\mathrm{P}$ ' values of all of these variables. For any variable to have a significant impact on outcomes, the corresponding 'P' value must be less than 0.05 .

Table 4. Regression results for influence on indigenous values

\begin{tabular}{|c|c|c|c|c|}
\hline & \multicolumn{2}{|c|}{ Individual Initiatives } & \multicolumn{2}{|c|}{ Similar initiatives added together } \\
\hline & Coefficients & P-Values & Country Initiatives & P-Values \\
\hline National Public Policies & --- & ---- & & \\
\hline National Private Policies & -108.66 & 0.410 & National Policies & 0.594 \\
\hline National Public Regulations & -690.96 & 0.002 & & \\
\hline National Private Regulations & 785.67 & 0.006 & National Regulations & 0.330 \\
\hline Regional Public Policies & 205.44 & 0.313 & & \\
\hline Regional Private Policies & -4683.65 & 0.000 & Regional Policies & 0.307 \\
\hline Regional Public Regulations & 4275.85 & 0.000 & & \\
\hline Regional Private Regulations & 4054.61 & 0.000 & Regional Regulations & 0.502 \\
\hline Provincial Public Policies & --- & --- & & \\
\hline Provincial Private Policies & --- & --- & Provincial Policies & .387 \\
\hline Provincial Public Regulations & -57.36 & 0.804 & & \\
\hline Provincial Private Regulations & 4220.40 & 0.000 & Provincial Regulations & .238 \\
\hline Local Public Policies & --- & --- & & \\
\hline Local Private Policies & -162.11 & 0.285 & Local Policies & .378 \\
\hline Local Public Regulations & 5418.60 & 0.000 & & \\
\hline Local Private Regulations & -5218.45 & 0.000 & Local Regulations & 0.929 \\
\hline Participation at Planning Phase & 3.44 & 0.975 & & \\
\hline Participation at Operation Phase & -15.75 & 0.853 & & \\
\hline Participation at Review Phase & -46.17 & 0.580 & Participation & 0.386 \\
\hline Foreign Direct Investments & -4.05 & 0.000 & FDI & 0.753 \\
\hline Poverty as $\%$ of GDP & 4.74 & 0.341 & Poverty & 0.528 \\
\hline Forests under plan management & -0.012 & 0.998 & $\begin{array}{c}\text { Forests under Plan } \\
\text { Management }\end{array}$ & 0.006 \\
\hline
\end{tabular}

Individual Initiatives: $R^{2}=0.999$, Adjusted $R^{2}=0.996$

Similar initiatives added together: $R^{2}=0.668$, Adjusted $R^{2}=0,226$

Coefficient for forests under plan management $=-47.37$.

Many of these variables have a significant impact on the indigenous concerns for the environment. The significant outcomes show that despite the absence of a direct relationship between these variables and indigenous values (except for national public regulations), they still indirectly impact environmental issues at local levels. Several conclusions can be drawn from the apparent low or no contribution of forests under public management plans to indigenous concerns for the environment when each initiative is analyzed individually: First, it is evident that commercial-oriented forestry initiatives are meant to serve the lumber needs of the country or those of the timber industry to a far greater extent than the needs of indigenous communities and their 
environmental values. Commercial forests do not provide a variety of vegetation types that meet indigenous needs such as medicinal products, fruits and arts and crafts. When the values of similar initiatives are added together, their regression outcomes are not significant except the forests under plan management. This is a clear indication that indigenous values are completely absent as an objective in ongoing policies and decentralization initiatives.

While there is already pressure to use available land and natural resources more intensively to meet individual needs locally, decentralization is expanding the use of all types of forests to meet national needs. Placing certain forests under a management plan does not appear to be even remotely related to conservation purposes, but rather has far more to do with supporting national economic development objectives. This confirms our second hypothesis that while indigenous communities are guided by values that commit everyone to protecting natural resources, governments at both the local and national scales desire to create wealth through the exploitation of natural resources.

\section{Discussion and Conclusions}

\subsection{Qualitative Analysis}

The majority of the literature makes very strong assertions that political and administrative decentralization is taking place to make public institutions more accountable, improve service delivery and accelerate economic growth. If and when these goals are realized, the entire social, economic, and environmental landscape in Africa will be transformed in ways that do not necessarily support environmental values. Economically and socially speaking, the expected changes will be positive, but they are likely to come at a huge cost to environmental sectors.

As many of the environmental programs are designed under an international framework and conventions with very little input from local communities, it is not surprising that many policies and regulations show little to no relationship with local cultural, social and environmental values. In the context of communication, there exists an elite group of people in many countries that distort the flow of information between communities and their governments. These types of outcomes do not support accountability and are partly the reason environmental values are being eroded to a greater extent during the era of decentralization.

National governments will continue to dominate the policymaking landscape even as local governments take more responsibility in the delivery of public service obligations. Whether local service delivery is more efficient and cheaper than when these same services were delivered by the national governments is not the focus of this study. The focus has been to determine if and to what extent decentralization has given rise to a governing structure that upholds and affirms the traditional values of marginal communities.

Local governments and indigenous communities are ill-equipped on many fronts, especially as they lack the administrative and fiscal capacity, human resources and technological base to facilitate innovation and make decisions that contract the broader micro-economic agenda. Insufficient local funding to support local program implementation increases dependence on national governments, thus making local decision-making vulnerable to elite capture.

\subsection{Quantitative Analysis}

From the quantitative findings, a credible conclusion can be made that there is little effort at all levels of government towards supporting indigenous concerns for the environment. While it is true that indigenous communities hold environmental and cultural values in high regard, the current onslaught of economic initiatives and investments that draw heavily upon environmental resources is creating a negative influence on these communities. This is the case especially in developing countries where natural resources are the immediate fallback response to addressing economic challenges for both governments and communities. National governments have done a poor job understanding local communities' values and aspirations besides economic development.

\subsection{Future Research}

One area that needs further research is an evaluation and analysis of the direction and overall impact on a country-specific level of policies, regulations and planning initiatives. This analysis, while addressing the differences between regional and provincial initiatives, would also determine both the environmental and economic impacts. It would go a long way in identifying for countries where decentralization has negative as well as positive impacts on indigenous values. Another challenge, albeit one that might have as much or more to do with policy as empirical research, is to devise better and more valid indicators to measure government performance in crafting policies and initiatives that fulfill indigenous values. As observed earlier, traditional 
indicators such as the percentage of forest area under a management plan have little bearing on concern for the environment when forests are being harnessed for commercial purposes to a greater extent than ever before.

\section{References}

Assan, J. K., \& Beyene, F. R. (2013). Livelihood Impacts of Environmental Conservation Programmes in the Amhara Region of Ethiopia. Journal of Sustainable Development, 6(10). https://doi.org/10.5539/jsd.v6n10p87

Assan, J. K., \& Hunt, S. (2018). Project Management and Community Participation within Small Island States: An Examination of Stakeholder Engagement in Belize in an Era of the Sustainable Development Goals. Journal of Sustainable Development, 11(2). https://doi.org/10.5539/jsd.v11n2p63

Bruce, J. W., \& Knox, A. (2009). Structures and Stratagems: Making Decentralization of Authority over Land in Africa Cost-Effective. World Development, 37(8). https://doi.org/10.1016/j.worlddev.2008.08.011

Caldeira, E., Foucault, M., \& Rota-Graziosi, G. (2012). Decentralization in Africa and the nature of local governments' competition: Evidence from Benin. National Bureau of Economic Research, Cambridge Massachusetts. https://doi.org/10.3386/w18126

Castro, A. P., \& Nielsen, E. (2007). Indigenous people and co-management: implications for conflict management. Environmental Science and Policy, (4), 229-239.

Chanie, P. (2009). Disconnect between public sector management and decentralization reforms: An empirical analysis of the Ethiopia situation. East African Social Science Review, 25(1), 59-91. https://doi.org/10.1353/eas.0.0007

Crawford, G., \& Hartmann, C. (2008). Decentralization in Africa: A pathway out of poverty. Amsterdam University Press. https://doi.org/10.5117/9789053569344

Crook, R. C. (2003). Decentralization and Poverty Reduction in Africa: The politics of local-central relations. Public Administration and Development, (23), 77-88. https://doi.org/10.1002/pad.261

Dickovick, J. T. (2014). Foreign Aid and Decentralization: Limitations on impact in autonomy and responsiveness. Public Administration and Development, 34, 193-205. https://doi.org/10.1002/pad.1691

Duncan, C. R. (2007). Mixed outcomes: The Impact of Regional Autonomy and Decentralization on Indigenous Ethnic Minorities in Indonesia. Development and Change, (4), 711-733. https://doi.org/10.1111/j.1467-7660.2007.00430.x

Estache, A., Garsous, G., \& Seroa da Motta, R. (2016). Shared Mandates, Moral Hazard and Political (Mis)alighment in Decentralization. World Development, 83, 98-110. https://doi.org/10.1016/j.worlddev.2016.02.006

Fereday, J., \& Muir-Cochrane, E. (2006). Demonstrating rigor using thematic analysis: A hybrid approach of inductive and deductive coding and thematic development. International Journal of Qualitative Methods. https://doi.org/10.1177/160940690600500107

Future Agricultures. (2011). Decentralization in Africa: Scope, Motivations and Impact on Service Delivery and Poverty - Overseas Development Institute.

Garret, T. A., \& Rhine, R. M. (2006). On the Size and growth of Government. Federal Reserve Bank of St. Louis Review, (88-1), 13-30.

German, L. A., Karsenty, A., \& Tiani, A.-M. (2010). Governing Africa's Forests in a Globalized World. Earthscan, USA.

Global Environmental Facility (GEF). (1996). Global Environmental Facility. Indigenous Communities and Biodiversity.

Hagen, J., \& Wolff, G. B. (2006). What do deficits tell us about debt? Empirical evidence on creative accounting with fiscal rules in the EU. Journal of Banking \& Finance, 30, 3259-3279. https://doi.org/10.1016/j.jbankfin.2006.05.011

Homewood, K. M. (2004). Policy, Environment and Development in African Rangelands.

Hope, K. R. Sr, \& Chikulo, B. C. (2000). Decentralization, the New Public Management, and the changing role of the public sector in Africa. Public Management, 2, 25-42. https://doi.org/10.1080/14719030000000002

Hulst, R., Mafuru, W., \& Mpenzi, D. (2015). Fifteen Years After Decentralization by Devolution: 
Political-Administrative Relations in Tanzanian Local Government. Public Administration and Development, 35, 360-371. https://doi.org/10.1002/pad.1743

International Union of Conservation of nature (IUCN). (2015). International Union for Conservation of nature standard on indigenous peoples.

Jank, B., Rath, J., \& Gaugisch, H. (2006). Subsidiarity. Trends in biotechnology, 24(5), 198-200. https://doi.org/10.1016/j.tibtech.2006.03.001

Kadirbeyoglu, Z. (2017). The impact of power and civic management in the decentralized management of natural resources: The case study of Turkey. Journal of Public Administration and Development, 37, 277-291. https://doi.org/10.1002/pad.1809

Kumar, K., Singh, N. M., \& Kerr, J. M. (2015). Decentralization and democratic forest reforms in India: Moving to a rights-based approach. Forest Policy and Economics, 51, 1-8. https://doi.org/10.1016/j.forpol.2014.09.018

Manyak, T. G., \& Katono, I. W. (2010). Decentralization and Conflict in Uganda. African Studies Quarterly, 11(4).

Martinez de Anguita, P., Martin, M. A., \& Clare, A. (2014). Environmental Subsidiarity as a guiding principle for forestry governance: Application to payment for ecosystem services and REDD+ architecture. Journal of Agricultural and Environmental Ethics, 27(4), 617-631. https://doi.org/10.1007/s10806-013-9481-8

Peters, P. E. (2008). Challenges in Land Tenure and Land Reform in Africa: Anthropological Contributions. World Development, 37(8). https://doi.org/10.1016/j.worlddev.2008.08.021

Qayyum, U., Din, M., \& Haider, A. (2014). Foreign aid, external debt and governance. Economic Modelling, 37, 41-52. https://doi.org/10.1016/j.econmod.2013.08.045

Ran, R. (2017, September). Understanding Blame Politics in China's Decentralized System of Environmental Governance: Actors, Strategies and Context. The China Quarterly, 231, 634-661. https://doi.org/10.1017/S0305741017000911

Reij, C., \& Garrit, D. (2016). Scaling up farmer-managed natural regeneration in Africa to restore degraded landscapes. The Journal of the Association for Tropical Biology and Conservation, 48(6), 834-843.

Smoke, P. (2015). Managing Public Sector Decentralization in Developing Countries: Moving beyond conventional recipes. Public Administration and Development, 35, 250-262. https://doi.org/10.1002/pad.1736

Smoke, P. (2015). Rethinking Decentralization: Assessing challenges to popular public sector reforms. Public Administration and Development, 35, 97-112. https://doi.org/10.1002/pad.1703

Stevens, S. (2014). Indigenous Peopls, National Parks, and Protected Areas: A new paradigm linking conservation, culture, and rights. The University of Arizona Press.

Tacconi, L. (2007). Decentralization, forests and livelihoods: Theory and narrative. Global Environmental Change, (17), 338-348. https://doi.org/10.1016/j.gloenvcha.2007.01.002

The World Bank. (2007). Indigenous Communities and Biodiversity. Global Environmental Facility.

The World Bank. (2013). Decentralization Indicators.

Turner, M. D., Ayantunde, A. A., Patterson, K. P., \& Patterson, E. D. (2011). Conflict Management, Decentralization and Agropastoralism in Dryland West Africa. World Development, 40.

Turner, S. (2009). Devolution as a barrier to environmental reform: Assessing the response to review of environmental governance in Northern Ireland. Journal of Environmental Law, 11, 150-160. https://doi.org/10.1350/enlr.2009.11.3.054

United Nations (UN). (2005). United Nations. Decentralization: Poverty Reduction, Empowerment and Participation. Economic and Social Affairs.

United Nations (UN). (2009). The state of the World's Indigenous Peoples. Department of Economic and Social Affairs. ST/ESA/328 United Nations publication Sales No. 09.VI.13.

United Nations Food and Agricultural Organization (UNFAO). (2015). Global Forest Resources Assessment 2015.

Vollan, B. (2012). Pitfalls of Externally Initiated Collective Action: A Case Study from South Africa. Leibniz 
Center for Marine Tropical Ecology (ZMT). World Development, 40, 758-770. https://doi.org/10.1016/j.worlddev.2011.09.016

World Wildlife Fund (WWF). (2000). World Wildlife Fund. Indigenous and traditional peoples of the world and ecoregion conservation. An Integrated Approach to Conserving the World's Biological and Cultural Diversity.

World Wildlife Fund (WWF). (2005). Mainstreaming WWF Principles on Indigenous Peoples and Conservation in Project and Program Management. World Wildlife Fund.

Yussof, M. A., Sarjoon, A., \& Hassan, M. A. (2016). An Analysis of the Development Impacts of Establishing Kalmunai Administrative District in Sri Lanka. Journal of Sustainable Development, $9(1)$. https://doi.org/10.5539/jsd.v9n1p164

\section{Copyrights}

Copyright for this article is retained by the author(s), with first publication rights granted to the journal.

This is an open-access article distributed under the terms and conditions of the Creative Commons Attribution license (http://creativecommons.org/licenses/by/4.0/). 